\title{
Distribution and co-existence of the Macropis species and their cleptoparasite Epeoloides coecutiens (Fabr.) in NW Europe (Hymenoptera: Apoidea, Melittidae and Apidae)
}

\author{
Antti Pekkarinen, Øistein Berg, Isabel Calabuig, Lars-Åke Janzon \& Jaan Luig
}

Pekkarinen, A., Berg, Ø., Calabuig, I., Janzon, L.-Å. \& Luig, J. 2003: Distribution and co-existence of the Macropis species and their cleptoparasite Epeoloides coecutiens (Fabr.) in NW Europe (Hymenoptera: Apoidea, Melittidae and Apidae). — Entomol. Fennica 14: 53-59.

The Macropis species collect pollen and fatty oil secreted by flowers of loosestrifes (Lysimachia, Primulaceae) and are the only known oil-collecting bees in the Holarctic. In NW Europe, L. vulgaris is the main or (in large areas) sole pollen and oil source for M. europaea Warncke (labiata auct.) and $M$. fulvipes (Fabr.). The species are largely sympatric in southern Finland and the Baltic countries, while in Scandinavia and most of Denmark only M. europaea has been recorded. The ranges of the Macropis species are restricted to the areas of common occurrence of $L$. vulgaris. Presumably, Epeoloides coecutiens has colonized Finland and Estonia since about 1970. The phenology of $M$. fulvipes is some days earlier than that of $M$. europaea, and this temporal difference may decrease resource competition in the co-existing populations.

Antti Pekkarinen, Department of Ecology and Systematics, P.O. Box 17, FIN00014 University of Helsinki, Finland; E-mail: antti.pekkarinen@helsinki.fi Øistein Berg, Kitty Kiellandsvei 19 C, NO-1344, Haslum, Norway; E-mail: oeistein.berg@c2i.net

Isabel Calabuig, Zoological Museum, University of Copenhagen, Universitetsparken 15,DK-2100 Copenhagen, Denmark; E-mail: icalabuig@zmuc.ku.dk

Lars-Åke Janzon, Section of Entomology, Swedish Museum of Natural History, Box 50007,S-10405 Stockholm, Sweden; E-mail: lars-ake.janzon@nrm.se Jaan Luig, Zoological Museum, University of Tartu, Vanemuise 46, EE51014 Tartu,Estonia; E-mail:jluig@ut.ee

Received 20 November 2002, accepted 4 March 2003

\section{Introduction}

The Holarctic genus Macropis Panzer comprises 16 recognized species of bees (Michener 2000). All species of the genus are believed to be strictly oligolectic and are specialized in collecting pollen exclusively from flowers of loosestrife (Lysimachia, Primulaceae). Three species of Macropis occur in the western Palaearctic region: M. fulvipes (Fabricius, 1804) (syn. M. labiata 
[Fabricius, 1804]), M. europaea Warncke, 1973 (M. labiata auct.) and M. frivaldskyi Mocsary, 1876 (see Warncke 1973). The two first-mentioned species occur in most of Europe, whereas $M$. frivaldskyi is found only in southern and southeastern Europe.

The oligolecty of Macropis species for loosestrife (Lysimachia) and the flowers being nectarless have long been known. However, fairly recently, the flowers of loosestrife have been discovered to secrete fatty oil as a floral reward. Oil-producing glandular hairs densely cover the connate base of the pistil and stamens of loosestrife flowers. The female bees collect the oil by absorption in specialized hairs situated on the tarsal segments of the fore and middle legs. The oil is mixed with pollen for nourishment of offspring (Vogel 1976, 1986).

Among several subgenera of the large and cosmopolitan genus Lysimachia, only the mainly Holarctic species of subgenus Lysimachia produce floral oil whereas the majority of species in other subgenera offer nectar as a floral reward. The range of the oil-producing species in Eurasia and North America covers that of the Macropis species. Southern China and neighbouring subtropic eastern Asia are especially rich in Lysimachia (s. str.) species; most of the approximately 85 species of the subgenus occur there, and many of them are oil producing (Vogel 1986). In subfamily Melittinae floral oil-collecting bees have been recorded apart from the Macropis species, in the South African genus Rediviva Friese and in subfamily Apinae among some Palaeo- and Neotropical tribes (Vogel 1986, Michener 2000).

Epeoloides species are nest parasites of the Macropis species (Michener 2000). Epeoloides coecutiens is the only Palaearctic species of the genus (Popov 1958) with a second species recorded in North America (Michener 2000).

\section{Material}

The material originates from the collections of museums of the Universities of Helsinki, Turku, Oulu, Lund, Oslo, Bergen, Copenhagen and Tartu, the Swedish Museum of Natural History, and private collections of the persons mentioned in the acknowledgements and those of the authors. The records from Latvia and Lithuania are based on the respective publications of Monsevičius (1995) and Tumss (1973, 1975).

\section{Food plants and nesting}

The main pollen and oil plant of the Macropis species in north-western Europe is L. (L.) vulgaris. The native (in southern Sweden, Denmark and the Baltic countries), partially cultivated and naturalized $L$. (L.) nummularia and the cultivated $L$. (L.) punctata are other pollen and oil sources in the area. In NW Europe the widely distributed $L$. (Naumburgia) thyrsiflora and in southern Sweden and Denmark $L$. (L.) nemorum do not secrete floral oil and produce only small amounts of pollen (Vogel 1986); Macropis species do not forage these, and the note by Snelling \& Stage (1995) concerning $M$. nuda (Provancher) visiting $L$. thyrsiflora is dubious (see also Simpson et al. 1983). The energy source for adult bees is nectar, which they collect from many plant species mainly with open corolla (Vogel 1986, Pekkarinen et al. 2000). The males collect only nectar, but they seem to fly in more or less regular routes around the loosestrife flowers. The routes are rather short, often not more than one metre on each side of the triangle or quadrat route. The males usually stop and sit at a particular place on a leaf where they wait for arriving females. When a female arrives, the male approaches her, lands and copulation proceeds on flowers. The males are attracted not only by female pheromones (Kullenberg 1956, Rozen \& Jacobson 1980) but also by appearence.

The nests occur in soil as small aggregations near loosestrife. The nest consists of a short burrow leading to a nest cavity from which some cells radiate. The cells are lined with a greenish-yellow waterproof substance, which is derived from Lysimachia floral oil. The lining ensures constant humidity for the pollen and prevents water entrance into the nest. As far as we know, all Macropis species are univoltine (Malyshev 1929, Phipps 1948, Rozen \& Jacobson 1980, Cane et al. 1983).

\section{Distribution}

M. europaea is recorded mainly from Europe and eastwards to Kazakh (Vogel 1986). M. fulvipes has a Transpalaearctic range and the form occurring in the Amur and Ussuriisk areas is regarded as a separate subspecies, M.f. amurensis Popov 
(Romankova 1995). Presumably, M. fulvipes has dispersed fairly late to western Europe from the east and has not reached Scandinavia or the British Isles.

In Finland, the two Macropis species have rather similar distributions. The species are also largely sympatric in the Baltic countries, while in Scandinavia and most of Denmark, only $M$. europaea has been recorded (only a few old records exist from the beginning of the last century of $M$. fulvipes on the Danish island of Lolland). In the Fennoscandian area, L. vulgaris has a large distribution, reaching as far as southern Lapland (Fig. 1). However, the ranges of the two bee species in Finland are mainly restricted to areas where L. vulgaris is common, i.e. shows a frequency of $40 \%$ (Fig. 1). Similarly, $M$. europaea occurs in Sweden and Norway only in the southern range of the distribution of $L$. vulgaris, approximately in the area where Hultén (1971) considered the plant to be common or very common (Fig. 1). In Russian Karelia, the records of Macropis species are scanty and their northernmost distribution is poorly documented.

Many oligolectic bee species in Europe have suffered from a decline in their pollen and nectar resources (e.g. Westrich 1990, Falk 1991, Pekkarinen 1998, 1999). L. vulgaris, a hygrophyte often growing abundantly at the edge of waters or in other damp places, has not been greatly impacted by changes in agriculture as have many other food flowers of bees. Consequently, the Macropis species are often locally abundant in the area in question.

Two old records of Epeoloides coecutiens are available from the Karelian Isthmus (Sahlberg 1889, Niemelä 1935). The species has been found on the Hanko Peninsula in southernmost Finland since 1970, and about thirty specimens have subsequently later been collected in several localities in southern Finland (even in Åland in 2002) (Viitasaari 1975, Ranta 1994, Pekkarinen et al. 2000; personal communications of J. Pöyry, J. Paukkunen, G. Söderman and I. Teräs) (Fig. 1). While Sagemehl (1882) did not note the species in the Baltic countries, it has been reported in a few localities in Lithuania since 1930 (Monsevičius 1995), and in Estonia since 1973. The species has not been recorded from Denmark or Scandinavia. The lack of old records and many new findings of E. coecutiens in Finland and Estonia imply a recent dispersal of this conspicuous species in NW Europe. Moreover, Schmiedeknecht (1930:834) characterized the species to be one of the rarest bee species in central Europe but, Westrich (1990), for example, regarded the species as fairly common locally in south-western Germany. By contrast, the American species E. pilosula (Cresson) may be extinct since no records have been made after 1942 (Michener 2000).

\section{Phenology}

L. vulgaris is the only native pollen and oil resource for the Macropis species in Finland. The main flight periods of the two bee species coincides with the height of the flowering of $L$. vulgaris in July. M. fulvipes has a slightly earlier occurrence, and the medians of flight dates (see large histograms in Fig. 2) and their differences (in days) between the species and the sexes are shown in Table 1.

The flight-date records (Table 1) originate over several decades and different sampling years, and variation in general phenology may be even some weeks during more extreme summers in southern Finland. Thus, a flight period of a single season is considerably shorter than indicated by the large multi-year histograms in Fig. 2. The small (black) histograms, indicating one flight season, imply that a maximal local flight period may be about one month (see also Rozen \& Jacobson 1980). In the (fairly small) Estonian material, the medians of the flight dates are as follows: $M$. fulvipes males 15.VII $(-0.4)(n=12)$, females 17.VII $(+0.1)$ $(n=15) ;$ M. europaea males 18.VII $(+0.5)$ $(n=22)$, females 1.VIII $(-0.2)(n=17)$.

\section{Co-existence}

To date, the Macropis species are the only known (regular) floral oil-foraging visitors of Lysimachia, and other insect groups, such as hoverflies, have been observed to eat only pollen (Vogel 1986). All Macropis species are oil foraging and are the principal pollinators of oil-producing loosestrifes. Thus, a long-continued mutualism between the 

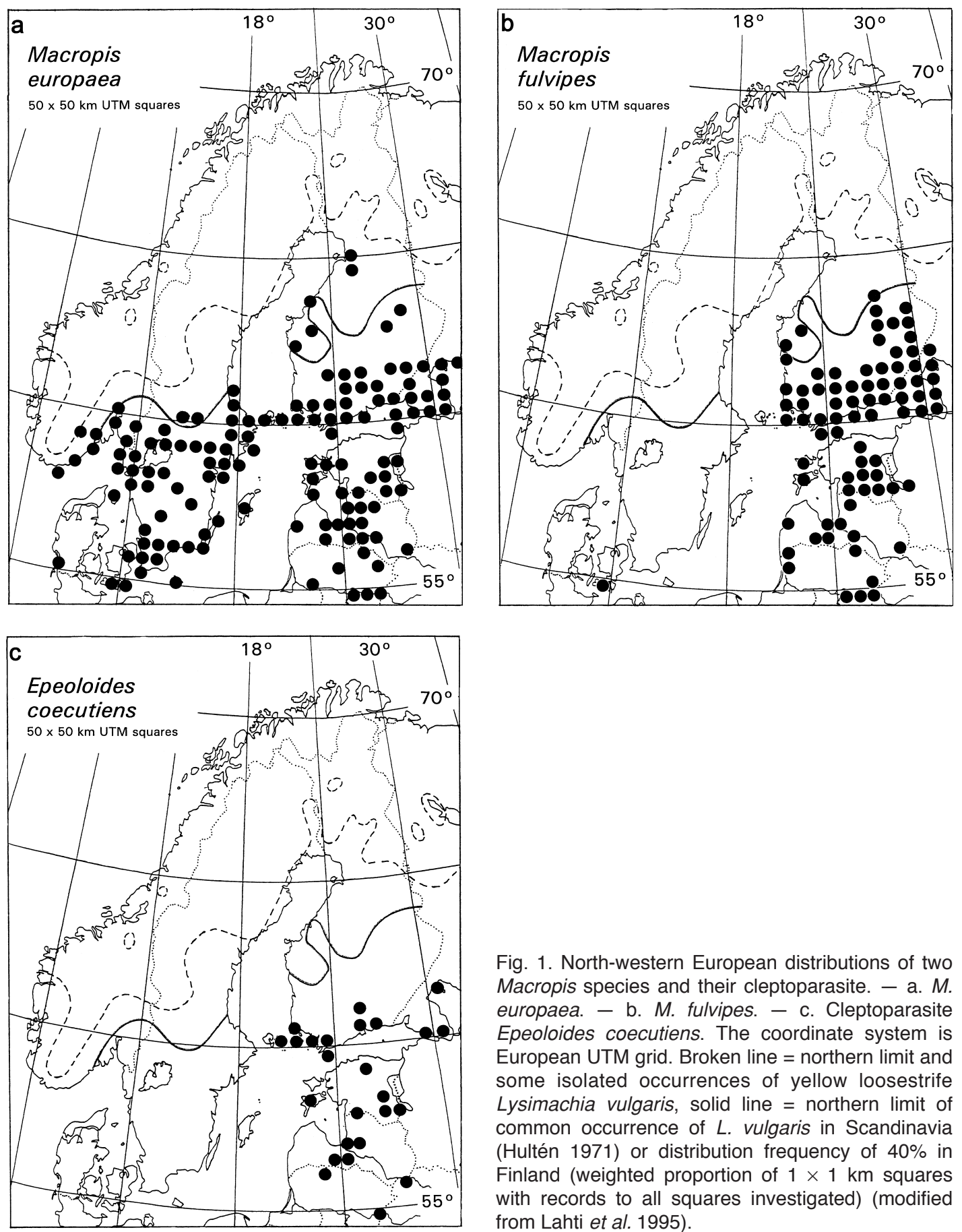

Fig. 1. North-western European distributions of two Macropis species and their cleptoparasite. - a. $M$. europaea. - b. M. fulvipes. - c. Cleptoparasite Epeoloides coecutiens. The coordinate system is European UTM grid. Broken line $=$ northern limit and some isolated occurrences of yellow loosestrife Lysimachia vulgaris, solid line $=$ northern limit of common occurrence of $L$. vulgaris in Scandinavia (Hultén 1971) or distribution frequency of $40 \%$ in Finland (weighted proportion of $1 \times 1 \mathrm{~km}$ squares with records to all squares investigated) (modified from Lahti et al. 1995).

loosestrifes and the Macropis species is evident. An eastern Asiatic species, M. ussuriana (Popov), which has been placed in the subgenus Paramacropis and regarded as a sister group of all other

Macropis species by Wu \& Michener (1986), has similar oil-collecting hairs to the other species of the genus, thus indicating old age of the mutualism. However, as Vogel (1986) emphasizes, the 
relationship has more likely been between groups of specialized pollinators and plants with specialized floral reward than mutualism between one bee and one plant species.

Oil-producing loosestrifes are also able to multiply vegetatively by means of autogamy or non-specialist pollinators, such as other bees and hoverflies (Cane et al. 1983, Simpson et al. 1983, Vogel 1986). Yet, few other bee species have been found to visit loosestrifes: Hylaeus confusus Nylander, H. hyalinatus F. Smith, Halictus tumulorum (L.) and four Bombus species in Finland (Niemelä 1934, Elfving 1968, pers. obs.); Westrich (1990) notes only Lasioglossum calceatum (Scopoli) in Baden Würtemberg. Some other bee genera have been recorded as visitors of Lysimachia: Heriades, Epeoloides, Ceratina, Allodape and Crocisa (Haman \& Koller 1956, Popov 1958, Wu 1965). Occasionally, some migrating species of hoverflies visit loosestrifes abundantly, including Episyrphus balteatus (De Geer) and Sphaerophoria scripta (L.) in southern Finland in 1998.

There are two or more sympatric Macropis species and several floral oil-producing Lysimachia species in a very large part of their common range. In North America, four largely sympatric Macropis and up to 17 native oil-producing Lysimachia species occur, while in Europe the corresponding figures are three and three (Simpson et al. 1983, Vogel 1986, Snelling \& Stage 1995). Thus, sympatric Macropis species may prefer different species of Lysimachia and avoid interspecific competition for pollen and oil resources; $M$. fulvipes, for instance, has been reported to favour early flowering L. nummularia, while M. europaea prefers later flowering L. vulgaris (Malysev 1929, Westrich 1990).

Finland has only one native oil-producing loosestrife species, and the two Macropis species
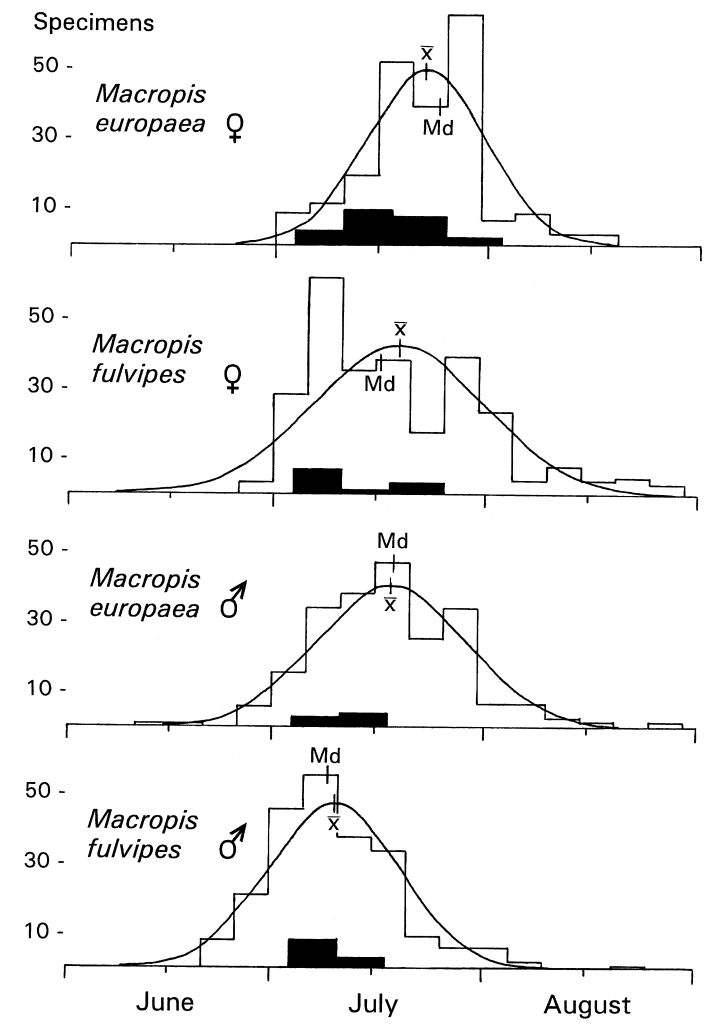

Fig. 2. Large histograms: dates (in five-day periods) of the Macropis species in Finland (from public and private collections). Small (black) histograms: dates (in approximately seven-day periods) of specimens collected by Malaise trap in 1983 in southern Finland (N: Sipoo 669:40). Curves of normal distribution have been drawn for large histograms $(\bar{x}=$ mean; $M d=$ median).

have to share the same larval food resource. They often co-exist in the same localities and may even forage on the same florescences of loosestrife. Moreover, the daily rhythm and the foraging behaviour of the two species seem to be similar and competition for food resources is possible. If the

Table 1. The median flight periods (large histograms in Fig. 2) of two Macropis species in Finland, and differences in flight periods (in days) indicated for sexes (right column) and for the species (lower row).

\begin{tabular}{llll}
\hline Species & Males & Females & Difference \\
\hline M. fulvipes & 9. VII $(+0.2)(n=227)$ & 16. VII $(-0.1)(n=276)$ & 6.7 \\
M. europaea & 18. VII $(+0.1)(n=228)$ & 24. VII $(-0.2)(n=223)$ & 5.7 \\
Difference & 8.9 & 7.9 & \\
\hline
\end{tabular}


flight period is 30 days and species occurrences follow a normal distribution, a median difference of five days between the species reduces temporal overlap by about $30 \%$, and the difference of ten days by about $60 \%$. Actually, the distributions in Fig. 2 are skewed and biased to the early (mean $>$ median; M. fulvipes) or the latter (mean $<$ median; $M$. europaea) part of the flight periods, and overlaps are thus even smaller than in normal distributions. Specific differences in flight periods of the coexisting Macropis species are therefore meaningful for resource partitioning.

Acknowledgements. We are grateful to the following persons for loans of bee specimens or providing other information or contributions: Anders Albrecht, Heli Alanne, Henning Bang Madsen, Roy Danielsson, Kaupo Elberg, Jukka Hari, Larry Huldén, Juhani Itämies, Seppo Karjalainen, Martti Koponen, Jaakko Kullberg, Tarja Martikainen, Mati Martin, Veli-Matti Mukkala, Teppo Mutanen, Sirkka-Liisa Nyéki, Juha Pöyry, Juho Paukkunen, Yrjö Ranta, Eino Räsänen, Eino Savolainen, Gunilla StåhlsMäkelä, Bo G. Svensson, Guy Söderman, Ilkka Teräs and Juha Viramo. Michael Kuhlman and Yuriy A. Pesenko made useful suggestions and corrections in the manuscript.

\section{References}

Cane, J. H., Eickwort, F., Wesley, R. P. \& Spielholz, J. 1983: Foraging, grooming and mate-seeking behaviors of Macropis nuda (Hymenoptera, Melittidae) and use of Lysimachia ciliata (Primulaceae) oils in larval provisions and cell linings. - Am. Midl. Nat. 110: 249-255.

Elfving, R. 1968: Die Bienen Finnlands. — Fauna Fennica 21: $1-69$.

Falk, S. 1991: A review of the scarce and threatened bees, wasps and ants of Great Britain. - Res. Surv. Nat. Conserv. 35: 1-344.

Haman, H. H. \& Koller, F. 1956: Die Wildbienen der Linzer Umgebung und ihre Flugpflanzen. — Naturkundl. Jb. Stadt Linz 1956: 327-361.

Hultén, E. 1971: Atlas of the distribution of vascular plants in northeastern Europe. 2. revised edition. Generalstabens Litografiska Anstalts Förlag, Stockholm. $531 \mathrm{pp}$.

Kullenberg, B. 1956: Field experiments with chemical sexual attractants on aculeate Hymenoptera males. Zool. Bidr. Uppsala: $253-354+5$ plates.

Lahti, T., Lampinen, R. \& Kurtto, A. 1995: Suomen putkilokasvien levinneisyyskartasto. [Distribution atlas of vascular plants in Finland.] Version 2.0. - Botanical Museum, Helsinki. 23 pp. + 1604 maps. [In Finnish].

Malyshev, S. I. 1929: The nesting habits of Macropis Pz. (Hym. Apoidea). - Eos 5: 99-109+ 3 plates.
Michener, C. D. 2000: The bees of the world. - The John Hopkins University Press, Baltimore and London. 913 pp.

Monsevičius, V. 1995: A check-list of wild bee species (Hymenoptera, Apoidea) of Lithuania with data to their distribution and bionomics. - New and rare for Lithuania insect species. Records and descriptions of 1994-1995: 7-145. Inst. Ecol. \& Lithuanian Entomol. Soc., Vilnius.

Niemelä, P. 1934: Eteläsuomalaisten pikkumehiläisten kukillakäynneistä. [Flower visits of solitary bees and honey bee in southern Finland.] - M.Sc. thesis, University of Turku. 526 pp. [In Finnish].

Niemelä, P. 1935: [A new bee genus and species for Finland, Epeoloides coecutiens F.] — Ann. Entomol. Fennici 1: 69. [Meeting report in Finnish].

Pekkarinen, A. 1998: Oligolectic bee species in Northern Europe (Hymenoptera, Apoidea). — Entomol. Fennica 8: 205-214.

Pekkarinen, A. 1999: Oligolectic bee species and their decline in Finland (Hymenoptera: Apoidea). — Proc. XXIV Nordic Congr. Entomol. in Tartu: 151-156.

Pekkarinen, A., Albrecht, A., Teräs, I. \& Viitasaari, M. 2000: Macropis europaea Warncke, M. fulvipes (Fabricius) and their nest parasite Epeoloides coecutiens (Fabricius) in Finland. - Sahlbergia 6: 21-28. [In Finnish with English abstract].

Phipps, J. 1948: The nest of Macropis labiata (F.) (Hym. Apidae). — Entomol. Month. Mag. 84: 56.

Popov, V. В. [Попов, В. Б.] 1958: Peculiar features of correlated evolution of two genera of bees - Macropis and Epeoloides (Hymenoptera, Apoidea) — and a plant genus Lysimachia (Primulaceae). - Entomol. Obozrenie 3: 500-519. [In Russian].

Ranta, Y. 1994: Epeoloides coecutiens (F.) loismehiläinen ja sen esiintyminen Suomessa. [The cleptoparasitic bee Epeoloides coecutiens (F.) and its occurrence in Finland.] — Diamina 3: 31. [In Finnish].

Romankova, T. G. 1995 [Романкова, Т. Г.]: Family Melittidae. — Ler, P. А. [Лep, П. А.] (ed.), [A determination guide to the insects of Russian Far East IV]: 528529. "Nauka". Sankt Petersburg. 607 pp. [In Russian].

Rozen, J. G., Jr. \& Jacobson, N. R. 1980: Biology and immature stages of Macropis nuda, including comparisons to related bees (Apoidea, Melittidae). - Amer. Mus. Novitates 2702: 1-11.

Sagemehl, M. 1882: Verzeichniss der in Est-, Liv- und Curland bisher gefundenen Bienen. - Archiv. Naturk. Livlands, Ehst und Kurlands II:8 4: 1-20.

Sahlberg, J. 1889; Catalogus praecursorius Hymenopterorum Anthophilorum Fenniae. - Medd. Soc. Fauna Flora Fennica 35: 31-52.

Schmiedeknecht, O. 1930: Die Hymenoteren Nord- und Mitteleuropas. - Verlag von Gustav Fischer, Jena. $1062 \mathrm{pp}$.

Simpson, B. B., Neff, J. L. \& Seigler, D. S. 1983: Floral biology and floral rewards of Lysimachia (Primulacae). — Amer. Midland Natur. 110(2): 249-256.

Snelling, R. R. \& Stage G. I. 1995: A revision of the Neartic Melittidae: the subfamily Melittinae (Hymenoptera: 
Apoidea). - Contrib. Sci. Nat. Hist. Mus. Los Angeles 451: 19-31.

Tumss, V. 1973: Materiali Latvijas bisu (Hymenoptera, Apoidea) faunai II. - Zoologijas muzeja raksti 11 (Invertebrata): 5-33.

Tumss, V. 1975. Materiali Latvijas bisu (Hymenoptera, Apoidea) faunai III. — Zoologijas muzeja raksti 13 (Invertbrata): 3-21.

Viitasaari, M. 1975: Epeoloides coecutiens F. (Hym., Anthophoridae) in Finland. - Ann. Entomol. Fennici 41: 43.

Vogel, S. 1976: Oil-collecting bees of the Old World and their flowers. - XV Intern. Entomol. Congr. Washington. Abstracts. [Reference according Vogel 1986].

Vogel, S. 1986: Ölblumen und ölsammelnde Bienen. Zweite
Folge. Lysimachia und Macropis. - Trop. Subtrop. Pflanzenwelt 54: 147-312.

Warncke, K. 1973: Die westpaläarktischen Arten der Bienenfamilie Melittidae (Hymenoptera). - Polskie Pismo Entomol. 43: 97-126.

Westrich, P. 1990: Die Wildbienen Baden Württembergs I-II. Second edition. - Verlag Eugen Ulmer, Stuttgart. $972 \mathrm{pp}$.

Wu, Yen-ju 1965: A study of Chinese Macropis with descriptions of two new species (Apoidea, Melittidae). — Acta Entomol. Sinica 14:591-599. [In Chinese with English summary].

Wu, Yan-ru (Yen-ju) \& Michener C. D. 1986: Observations on Chinese Macropis (Hymenoptera: Apoidea: Melittidae). — J. Kansas Entomol. Soc. 59: 42-48. 